\title{
Implementation of Problem-Based Learning Model to Facilitate the Understanding of Information System Audit Materials
}

\author{
Andi Basru Wawo ${ }^{1}$, Tuti Dharmawati ${ }^{2}$ \\ DOI: $10.35445 /$ alishlah.v13i2.979
}

\begin{tabular}{l} 
Article Info \\
\hline Keywords: \\
Problem-Based \\
Learning; \\
Students; \\
Information System \\
Audit
\end{tabular}

Kata kunci:

Pembelajaran Berbasis Masalah;

Siswa;

Audit Sistem Informasi

\begin{abstract}
This study aims to determine and improve students' understanding of the Information System Audit material using the problem-based learning model. It is hoped that this research can provide benefits for the development of effective learning models to support the formation of the personality and scientific qualities of students and improve the skills of lecturers in developing learning models. This research is a classroom action research with a problem-based learning model. The research subjects are students studying at the Accounting Study Program, Faculty of Economics, Halu Oleo University in the 2018/2019 academic year who take information systems audit courses. The results showed that implementing the problem-based learning model could improve students' understanding of the information system audit material. It can be seen through an increase in students' complete learning from before when the pre-test was $0 \%$ in a row; from each cycle, there was an increase until the post-test was 95.6\%. Students' interest in inactiveness and collaboration is also good, namely 3.44 (scale 1-4). This study also found that the problem-based learning model improved students' ability to solve problems, think critically, and build their knowledge because information systems audit materials require direct skills and in-depth understanding.
\end{abstract}

\begin{abstract}
Abstrak
Penelitian ini bertujuan untuk mengetahui dan meningkatkan pemahaman siswa terhadap materi Audit Sistem Informasi dengan menggunakan model pembelajaran berbasis masalah. Diharapkan penelitian ini dapat memberikan manfaat bagi pengembangan model pembelajaran yang efektif untuk mendukung pembentukan kepribadian dan kualitas keilmuan mahasiswa serta meningkatkan keterampilan dosen dalam mengembangkan model pembelajaran. Penelitian ini merupakan penelitian tindakan kelas dengan model pembelajaran berbasis masalah . Subjek penelitian adalah mahasiswa Program Studi Akuntansi Fakultas Ekonomi Universitas Halu Oleo tahun ajaran 2018/2019 yang mengambil mata kuliah audit sistem informasi. Hasil penelitian menunjukkan bahwa penerapan model pembelajaran berbasis masalah dapat meningkatkan pemahaman siswa terhadap materi audit sistem informasi. Hal ini terlihat melalui peningkatan ketuntasan belajar siswa dari sebelumnya saat pre-test sebesar $0 \%$ berturut-turut; dari setiap siklus terjadi peningkatan hingga post-test sebesar $95,6 \%$. Minat siswa terhadap
\end{abstract}

\footnotetext{
${ }^{1}$ Universitas Halu Oleo, Kendari, Indonesia

Email: andi.basruwawo@yahoo.co.id

2 Universitas Halu Oleo, Kendari, Indonesia

Email: tutidharmawati@gmail.com
} 
ketidakaktifan dan kerjasama juga baik yaitu 3,44 (skala 1-4). Penelitian ini juga menemukan bahwa model pembelajaran berbasis masalah terbukti dapat meningkatkan kemampuan belajar siswa dalam memecahkan masalah, berpikir kritis, dan membangun pengetahuannya karena materi audit sistem informasi memerlukan keterampilan langsung dan pemahaman yang mendalam.

\section{INTRODUCTION}

Education is a way to form quality human resources to support national development goals (Widiansyah, 2018). The educational process occurs when an interaction between educational components is functionally interconnected in an integrated unit. Academic success or failure is highly reliant on students' learning process both on campus and in their own home or family setting (Van Driel et al., 1997). Learning is the process through which an individual attempt to modify his or her overall behavior due to personal experience in connection with his or her surroundings (Clark, 2012).

The quality of learning is initially demonstrated via the continual development of fundamental attitudes such as a scientific, academic critical attitude and a willingness to seek the truth (Howieson, 2003). Thus, education cannot be limited to a test that simply evaluates information transfer but must encompass the development of fundamental abilities and attitudes, such as being critical, creative, and receptive to new ideas and discoveries. All of this is necessary to live and respond to the ever-changing difficulties of daily life (Burnett, 2003). Thus, educators are also required to act as a transfer of knowledge, but more than that, they also act as agents of change. In this case, the idealism of educators will help students produce and develop innovation and knowledge (Villegas \& Lucas, 2002).

The Long Term Strategy for Higher Education 2003-2010, issued by the Directorate of Higher Education in April 2003, mandates the Student-Centered Learning (SCL) principle in all aspects of learning (Wright, 2011). SCL is critical to implement to increase the quality of learning and hence the competency and learning outcomes of students enrolled in a course. SCL is used in various ways to implement learning, including problem-based and cooperative learning approaches (Utami et al., 2010).

Information Systems Audit is a course designed to equip students to audit business entities implementing computerized information systems (Sutabri, 2012). This course is a logical consequence for the auditor profession because of the application of information technology in the company's transaction processing system. The computerized information system will cause changes in the characteristics of the transaction processes that occur so that audit activities also experience changes in the nature, scope, and audit techniques (Agung \& Andry, 2018). The discussion of this course material will begin with the understanding, characteristics, and extent of Information Systems Audit. Then, material about information technology risk management and internal control models in computerized information systems will be discussed (Fauzi, 2017).

Further discussion on the impact of information technology applications, such as ERP systems, e-commerce, and e-business, on implementing information technology-based audits. In addition, audit software will also be discussed as an auditor's tool used in collecting and testing electronic evidence. In the end, the need for understanding various computer-assisted audit techniques is a method that cannot be ignored in this information system audit (Putra \& Noviari, 2013).

The phenomenon related to the Information System Audit learning process practiced today is more dominant in tutorials/lecturings. The application of learning methods like this in lectures, activities carried out by students are in the form of listening to lecturers, and students together understand what the lecturers say while making notes as necessary (Aziz et al., 2020). The role of the lecturer in the application of the lecture method is the center of attention. Thus the effectiveness in achieving learning outcomes is less than optimal. Lecturers seem to be the center of the "source of knowledge." This "lecturer-centric" learning pattern has very low effectiveness because the 
lecturers are active while the students are passive. Learning with the application of this method focuses more on understanding the material. As a result, students do not have a comprehensive picture of applying the material in the business world (Nurhayati, 2015). Thus, this learning method will result in not achieving the expected learning outcomes of students, such as analytical competence, problem-solving competence, and the competence to evaluate problems holistically. Whereas following the Indonesian National Qualifications Framework (KKNI), it has been determined that $\mathrm{S} 1$ graduates (bachelors) are expected to reach level 6, namely "analysis. This is in line with the nature of the audit process, which is analytical (Faridah et al., 2021).

In light of the issues above, the recommended mode of instruction for the information system audit course is problem-based learning. The primary reasons for presenting problem-based learning in lectures are as follows: (1) learning requires illustrations of confirmed cases in the application of knowledge or concepts obtained from lectures and textbooks; (2) lecture-based learning alone frequently renders students passive; and (3) effective learning is a process that includes reflection (double-loop learning) (Yeo, 2008). Problem-based learning is a type of learning that enables the occurrence of double-loop learning. In the realm of education, a well-known adage is, "explain me and I will forget; show me, and I will remember; include me, and I will comprehend." It is anticipated that engaging students in problem-based learning would get more profound knowledge than they would if they were just required to accept the theory (Enemark, 2016).

The anxiety of parents, students, and the public about the quality of college graduates demands reform of the institution, from lecturers to leaders, so an educational atmosphere should be created (Hershatter \& Epstein, 2010). The theoretical mentality and tex-books in learning must be updated with knowledge, honesty, solidarity, and openness to the surrounding reality. Listening attitude should also not be ignored in education because without such an attitude. There will be a distortion of understanding and thinning of sensitivity (Nias, 1996).

Problem-based learning, sometimes referred to as the Problem-Based Learning (PBL) learning paradigm, is a form of student-centered learning that begins with real-world issues (Savery, 2015). According to De Graaf \& Kolmos (2003), PBL is a model of learning that enables students to understand how to learn and collaborate in groups to solve real-world issues. Implementing the Problem-Based Learning (PBL) learning paradigm originates from the belief that students would be better able to exercise their critical thinking abilities if they are actively involved in addressing an information systems auditing problem (Schmidt, 1983). Lecturers can facilitate this process by offering feedback to students and encouraging them to collaborate to discover or apply their ideas while evaluating and addressing an issue (Nisak \& Sari, 2013).

The Problem Based Learning learning model is a method of instruction that uses real-world issues as a framework for students to exercise critical thinking, develop problem-solving abilities, and acquire information and critical ideas from instructional materials. debated (Fristadi \& Bharata, 2015). The Issue-Based Learning methodology begins with a problem that students or lecturers might raise, and then students build on their prior knowledge and learn what they need to know to solve the problem. Students can select issues that they find fascinating to tackle to be encouraged to take an active role in their education (Istiningrum, 2017).

According to Tjipto and Ruijter (1991), problem-based learning is a form of instruction that encourages students to solve problems methodically. According to their observations, pupils frequently encounter four barriers while attempting to solve problems: 1 . Students do not conduct in-depth analyses of the situations they encounter. 2. The students do not plan the answer. 3 . Students do not provide detailed responses to the questions. 4. Students are no longer required to evaluate the accuracy of calculations/answers.

According to the explanation, modifications to learning techniques are required. Initially dominating methods of instruction, such as tutorials, evolved into methods that empowered students. This is because universities are primarily centers of learning rather than classrooms where 
professors teach. About the shift in instructional techniques, researchers are interested in determining the effect of using the case-based learning approach on the output of the learning process, particularly the degree of knowledge achieved by students enrolled in the information system audit course.

\section{METHODS}

This study uses a classroom action research method. This research is all students who take the Information Systems Audit course at the Accounting Study Program, Faculty of Economics (FE) Halu Oleo University, Kendari. The classroom action research procedure is an activity cycle consisting of two processes. Each process includes planning/preparation, implementation, analysis, and reflection. The reflection results in the first cycle are used to refine the actions in the following method. The work procedure can be explained with a flow chart as follows:

a. Preparation. At this stage, the identification of problems is carried out carefully by digging up complete data, both students and lecturers.

b. Action implementation. In the first cycle, learning was carried out using the problem-based learning method. One of the lecturers in the Auditing course is the performance of knowledge, a research partner lecturer. At the same time, the other research team was an observer of the learning activities.

c. Observation. Observations or observations of actions for each cycle are carried out during the learning process.

d. Analysis and reflection. In this activity, an investigation will be carried out based on the results of observations. The results of the comments were conveyed in a joint discussion between the lecturer and the observer team (research team). The debate will be discussed about matters relating to the implementation of learning. The analysis results in the form of input will be used to improve the performance of the learning process in the next cycle.

Details of each cycle can be seen in the following description:

\section{CYCLE 1}

Subject: Audit Evidence

1. Time: 4 times meeting

2. Learning Method: Problem

Based Learning

3. Location: Classroom and environment around campus.

4. Evaluation: Interest and student learning outcomes

\section{CYCLE 2}

Subject Matter: Understanding the Internal Control Structure

1. Time: 4 meetings

2. Learning Method: Problem

Based Learning

3. Location: Classrooms and

campus surroundings

4. Evaluation: Interest and

student learning outcomes

\section{CYCLE 3}

Subject Matter: impact of information technology applications

1. Time: 4 meetings

2. Learning Method: Problem

Based Learning

3. Location: Classrooms and campus surroundings

4. Evaluation: Interest and student learning outcomes

The data collected were analyzed using descriptive analysis. This data analysis was used to analyze the results of observations regarding student enthusiasm or interest, the quality of learning carried out by lecturers during the implementation of actions, and student learning outcomes. In this classroom action research, the researcher determines the student's learning completeness with a minimum of 71 or B. Students are said to have completed their studies if they have achieved a minimum score of B. Meanwhile, the criteria for student interest in learning, student participation in education, and lecturers' skills in providing lecture material are used. With a range of 1-4 in each aspect/category observed. If the observer puts a checkmark on:

- Number 1 means that the aspect observed is not good

- Number 2 means that the aspects observed are sufficient

- Number 3 means the observed aspect is good

- Number 4 means the observed aspect is very good 


\section{FINDINGS AND DISCUSSION}

By applying the problem-based learning technique in the classroom, we want to increase student success and learning quality. The following table summarizes the findings from the study:

Table 1. Data Analysis Results About Student Achievement

\begin{tabular}{lccccc}
\hline Value Description & Pre Test & Cycle 1 & Cycle 2 & Cycle 3 & Post Test \\
\hline Lowest Value & 22 & 40 & 50 & 65 & 73 \\
Highest Value & 63 & 74 & 82 & 85 & 97 \\
Mean & 44.2 & 55.4 & 69.5 & 74.5 & 84.7 \\
Complete Learning & $0 \%$ & $12 \%$ & $45,2 \%$ & $61.7 \%$ & $95.6 \%$ \\
\hline
\end{tabular}

Based on the criteria of completeness mentioned above, in the initial state (before being given action) and the final form after being given the movement, are as follows: in the initial state, o\% achieved complete learning, while in the first cycle, $12 \%$ achieved thorough understanding, in the second cycle which gained complete learning $45.2 \%$, in the third cycle achieved complete learning $61.7 \%$. In the final test, which conducted complete learning, $95.6 \%$

Management of learning by lecturers by implementing problem-based learning methods during learning activities that are observed with observation guidelines, the results can be seen in the table below:

Table 2. Data on Observation of Lecturer Skills in Learning Management using Problem Based Learning Method

\begin{tabular}{llcccc}
\hline No & \multicolumn{1}{c}{ Variable Observed } & $\begin{array}{c}\text { Cycle 1 } \\
\text { Score }\end{array}$ & $\begin{array}{c}\text { Cycle 2 } \\
\text { Score }\end{array}$ & $\begin{array}{c}\text { Cycle 3 } \\
\text { Score }\end{array}$ & Mean \\
\hline 1 & Use of language by lecturers & 3 & 3 & 4 & 3.33 \\
2 & Learning atmosphere & 3 & 3 & 4 & 3.33 \\
3 & Variations in the use of learning & 3 & $3 \cdot 5$ & 4 & 3.5 \\
& resources & 3 & $3 \cdot 5$ & 3.5 & 3.33 \\
4 & Media usage accuracy & 3 & 3 & 3.5 & 3.17 \\
5 & Accuracy of using a method & $3 \cdot 5$ & 3.5 & 4 & 3.67 \\
6 & Appreciation for students & 3 & 3.5 & 4 & 3.5 \\
7 & Evaluation accuracy & & & & 3.40 \\
8 & Mean & & & & \\
\hline
\end{tabular}

The table above shows the skills of lecturers in learning management with an assessment range of 1-4 in the excellent category (means of all aspects observed is 3.40). The table above also shows an increase in lecturers' skills in learning management which is getting better in the next cycle. As for the interest, activity, and collaboration of students in the auditing learning process, it can be seen from the following data:

Table 3. Data on Observation Results regarding Interest, Activeness, and Cooperation of Students during the Learning Process

\begin{tabular}{clcccc}
\hline No & \multicolumn{1}{c}{ Observed aspects } & $\begin{array}{c}\text { Cycle 1 } \\
\text { Score }\end{array}$ & $\begin{array}{c}\text { Cycle 2 } \\
\text { Score }\end{array}$ & $\begin{array}{c}\text { Cycle 3 } \\
\text { Score }\end{array}$ & Mean \\
\hline 1 & Student interest & 3 & 3.5 & 3.5 & $3 \cdot 33$ \\
2 & Student Activity & 3 & 3.5 & 4 & 3.5 \\
3 & Students work in the learning process & 3 & 3.5 & 4 & 3.5 \\
4 & Mean & & & & 3.44 \\
\hline
\end{tabular}

The table above shows that the overall aspects observed regarding students are good with an average of 3.44. The table also shows an increase in student interest, activity, and collaboration in the next cycle.

The problem-based learning method in learning information systems audit courses is an effort to increase students' activities, interests, and learning achievements. In student-centered learning, the role of the lecturer is not as a center but only as a facilitator. So that students are active 
in solving problems, arguing, discussing, and concluding from the results of their discussions. A problem-based learning approach that prepares situations that provide challenges with various cases to be solved will make students experiment, search for data, ask questions, argue, and find solutions to a problem (Zubaidah, 2017).

The first cycle of the learning process is the cycle with the subject of audit evidence. Students are expected to explain audit evidence, distinguish various audit procedures, and distinguish between audit procedures and programs. In this first cycle, students were initially asked to do research related to audit evidence. This research was conducted in institutions and banks which are located close to the campus. After the research is done, the students discuss the problems in the field related to audit evidence in class. After that, students are expected to solve the case through discussion and sharing between friends. After this process is carried out, students operationalize audit evidence with conditions in the field.

In the first cycle, student learning outcomes reached $12 \%$ completeness, an increase of $12 \%$ from the initial condition. The atmosphere of the class during the discussion was quite lively and lively. Students who are usually afraid to ask questions or respond to their colleagues' opinions become enthusiastic and interested in solving cases on the subject of audit evidence. The material that was initially less attractive with this learning method became more interesting. However, in this first cycle, the activities of the students were not comprehensive; there were only a few people. In addition, a collaboration between students in discussions is also not optimal.

In the next cycle, after getting feedback from the lecturer in the first cycle, the activity began to be more visible from the first cycle. The skills of lecturers in implementing problem-based learning methods have also increased. It can be seen from the table of observational data regarding the skills of lecturers in learning management. However, in this cycle, there are still things that need attention, namely the way students analyze problems that are still less systematic. From several discussions that have been carried out, students still have difficulty making conclusions about the issues discussed. In the second cycle, student learning outcomes are $45.2 \%$. In the third round, student learning outcomes increased, and completeness at the final test reached 95.6\%.

In the third cycle, student activity increased, the class atmosphere was more lively, the difficulty in concluding a problem solving was no longer found. The ability to collaborate, communicate and present research results in information systems audit materials is satisfactory. Students are no longer oriented to memorization but understanding concepts by thinking critically and logically about a case on auditing material. In the third round, the class atmosphere is more conducive; students understand their roles and functions in group discussions and faster analyze a problem.

The primary purpose of applying this problem-based learning method is to understand a concept with an analytical, critical, and logical approach. So that research on cases or problems raised in lectures will make students more enthusiastic in lectures and hone them to think critically, communicate, issue arguments and work together in groups (Saleh, 2013). Through these problems or cases, students are expected to find concepts from information systems audit materials. An indepth understanding of the concept of information systems auditing through the operationalization of the concept will make it easier for students when they are in the world of work later in deciding on an audit activity on information technology systems.

This method also bridges between the concept and the reality in the field. It is done at the research setting stage. In each cycle, students seem more enthusiastic and have an interest in learning a new subject. Activities carried out by lecturers in each round with lesson plans prepared reduce lecturers' dominance in the learning process. This is because students are actively involved in conducting research and discussing. The use of learning resources looks effective, with the average of all aspects 3.33 from a range of 1-4; the lecturer applies the design as stated in the lesson plan. The lecturer only functions as a facilitator in the lecture process. 
Students' increased enthusiasm and activity in the experimental class due to the problembased learning paradigm's treatment encourages students to be motivated and engaged in executing learning activities. Students' interest and focus on the topic have risen due to the Problem Based Learning approach, which exposes students to real-world situations, increasing their curiosity to solve issues. This is also supported by the recitation method, which gives assignments to students, both projects that must be done in class or terms that are done outside the classroom. This task requires students to find many learning resources to complete assignments correctly and on time. Projects are given individually to raise the spirit to work independently so that students will be more active in working. Group assignments that are done together indirectly encourage students to work together with other friends. The existence of group discussion elements encourages student learning activities to be better because they can exchange opinions which, of course, will increase student motivation and actions. Presenting the results of assignments both individually and in groups in front of the class is considered an effective way to improve understanding of the material. The appointment of students for presentations encourages students to prepare themselves better so that productions run smoothly and get maximum grades. This motivates students to be more active in learning, active in understanding, studying, and completing tasks given by lecturers (Baidilah, 2016).

With this task, students must be more active in finding more references for learning resources to complete the job. The time limit given by the lecturer encourages students to do assignments on time. Tasks assigned individually raise the spirit to work independently. Group assignments that are done together in teams indirectly encourage students to work together with other friends. The existence of discussion in groups requires students to provide opinions, so they must prepare themselves well not to be embarrassed by other group members. Presenting the results both individually and in groups in front of the class is considered an effective way to improve understanding of the material. The appointment of students for presentations encourages students to prepare themselves better so that productions run smoothly and get maximum grades. This motivates students to be more active in learning, active in understanding, studying, and completing assignments given by lecturers. The increase in student activity will indirectly affect the way students learn and affect learning outcomes.

Combining problem-based learning (PBL) models with information systems audit materials is a practical activity. This information system audit material requires a deep and thorough understanding which is, of course, very difficult to accept if the learning model used is not suitable and does not provide in-depth knowledge to students. When applied in information systems audit materials, this learning model can also help students improve their ability to solve problems, think critically, and compile their knowledge by solving an issue that has been implemented. It is hoped that students can increase their understanding of the lecturer's material in this case. It will affect student learning outcomes for information system audit materials.

\section{CONCLUSION}

The research conducted on implementing problem-based learning models in increasing understanding of information system audit materials shows an increase in each cycle. It can be seen that when the initial state (pre-test) of complete learning was at $0 \%$, then there was an increase in cycle 1 to $12 \%$. There was an increase in complete learning to $45.2 \%$ in the second cycle. In the third cycle, $61.7 \%$ achieved complete learning and $95.6 \%$ at the end of comprehensive learning. Meanwhile, students' interests, activity, and collaboration during learning with a scale of 1 to 4 are in a good position, with an average of 3.44. Meanwhile, lecturers' observations in managing lectures with the problem-based learning model are also in a good job, namely using 3.40 with a scale of 1-4.

By incorporating the problem-based learning model into the information system audit course, students' ability to solve issues, think critically, and expand their knowledge may be enhanced by implementing a problem-solving process. It demonstrates that the learning model is appropriate and consistent for use with information systems audit learning materials. The material 
requires direct skills and a more profound understanding, which students can better grasp if directed to a real-world problem that must be solved.

\section{REFERENCES}

Agung, H., \& Andry, J. F. (2018). Audit Sistem Informasi Akademik Menggunakan Kerangka Kerja COBIT 5 pada Domain EDM pada Universitas XYZ. JBASE-Journal of Business and Audit Information Systems, 1(1).

Aziz, A. M. N., Andhika, A., Andriansyah, B. O. E., Alam, J., Permana, R., Deni, S., ... \& Firmansyah, R. (2020). Audit Sistem Informasi Menggunakan Framework Cobit 4.1 Pada E-Learning Ars University. Journal of Information System, Applied, Management, Accounting and Research, 4(3), 132-139.

Baidillah, I. (2016). Penerapan Problem Based Learning Dalam Kerangka Lesson Study Untuk Meningkatkan Kemampuan Berpikir Kritis Dan Hasil Belajar Akuntansi Siswa. Journal of Accounting and Business Education, 2(4).

Burnett, S. (2003). The Future of Accounting Education: A Regional Perspective. Journal of Education For Business, 78(3), 129-134.

Clark, I. (2012). Formative Assessment: Assessment is For Self-Regulated Learning. Educational Psychology Review, 24(2), 205-249.

De Graaf, E., \& Kolmos, A. (2003). Characteristics of Problem-Based Learning. International Journal of Engineering Education, 19(5), 657-662.

Enemark, S. (2016). Applying A Problem Based Learning Approach to Land Management Education: The Case Of Aalborg University, Denmark.

Faridah, N. L., Hakim, L., \& Yafi, M. F. (2021). Analisis Penerapan Kurikulum Kerangka Kualifikasi Nasional Indonesia (KKNI) pada Prodi S1 Pendidikan Ekonomi Universitas Negeri Surabaya dan STKIP PGRI Jombang. Edunusa: Journal of Economics and Business Education, 1(1), $1-14$.

Fauzi, R. A. (2017). Sistem Informasi Akuntansi (Berbasis Akuntansi). Deepublish.

Fristadi, R., \& Bharata, H. (2015). Meningkatkan Kemampuan Berpikir Kritis Siswa Dengan Problem Based Learning. In Seminar Nasional Matematika Dan Pendidikan UNY (Pp. 597602).

Hershatter, A., \& Epstein, M. (2010). Millennials and The World of Work: An Organization and Management Perspective. Journal of Business and Psychology, 25(2), 211-223.

Howieson, B. (2003). Accounting Practice in The New Millennium: is Accounting Education Ready to Meet The Challenge? The British Accounting Review, 35(2), 69-103.

Istiningrum, A. A. (2017). Peningkatan Self-Regulated Learning Skills Mahasiswa pada Mata Kuliah Akuntansi Pengantar melalui Problem-Based Learning. Jurnal Cakrawala Pendidikan, 36(1), 81-90.

Murniati, A., \& Hermawan, A. (2017). E-Problem Based Learning (E-Pbl) Pada Mata Kuliah Akuntansi Manajemen Sebagai Alternatif Pembelajaran Inovatif. Jurnal Ilmiah Bisnis Dan Ekonomi Asia, 11(1), 1-10.

Nias, J. (1996). Thinking about Feeling: The Emotions in Teaching. Cambridge Journal of Education, 26(3), 293-306.

Nisak, C., \& Sari, A. R. (2013). Penerapan Model Problem Based Learning untuk Meningkatkan Aktivitas dan Prestasi Belajar Akuntansi. Jurnal Pendidikan Akuntansi Indonesia, 11(1).

Nurhayati, F., Widodo, J., \& Soesilowati, E. (2015). Pengembangan LKS Berbasis Problem Based Learning (PBL) Pokok Bahasan Tahap Pencatatan Akuntansi Perusahaan Jasa. Journal Of Economic Education, 4(1).

Putra, P. S. S., \& Noviari, N. (2013). Pemanfaatan Teknologi Informasi, Kepercayaan, Dan Kompetensi Pada Penerapan Teknik Audit Sekitar Komputer.E-Jurnal Akuntansi, 4(3), 640-654.

Saleh, M. (2013). Strategi Pembelajaran Fiqh dengan Problem-Based Learning. JURNAL ILMIAH DIDAKTIKA: Media Ilmiah Pendidikan Dan Pengajaran, 14(1).

Savery, J. R. (2015). Overview Of Problem-Based Learning: Definitions and Distinctions. Essential Readings in Problem-Based Learning: Exploring and Extending the Legacy of Howard $S$. Barrows, 9(2), 5-15.

Schmidt, H. G. (1983). Problem-Based Learning: Rationale and Description. Medical Education, 17(1), 11-16. 
Sutabri, T. (2012). Konsep Sistem Informasi. Andi.

Tangke, N. (2004). Analisa Penerimaan Penerapan Teknik Audit Berbantuan Komputer (TABK) Dengan Menggunakan Technology Acceptance Model (TAM) Pada Badan Pemeriksa Keuangan (BPK) RI. Jurnal Akuntansi dan Keuangan, 6(1), 10-28.

Utami, B., Sugiharto, S., \& Indriyanti, N. Y. (2010). Penerapan Pendekatan Konstruktivisme Untuk Meningkatkan Pembelajaran Strategi Belajar Mengajar. Paedagogia, 13(2).

Utomo, T., \& Ruijter, K. (1991). Peningkatan Dan Pengembangan Pendidikan. Jakarta: Gramedia Pustaka Utama.

Van Driel, J. H., Verloop, N., Van Werven, H. I., \& Dekkers, H. (1997). Teachers' Craft Knowledge and Curriculum Innovation in Higher Engineering Education. Higher Education, 34(1), 105122.

Villegas, A. M., \& Lucas, T. (2002). Preparing Culturally Responsive Teachers: Rethinking the Curriculum. Journal of Teacher Education, 53(1), 20-32.

Widiansyah, A. (2018). Peranan Sumber Daya Pendidikan sebagai Faktor Penentu dalam Manajemen Sistem Pendidikan. Cakrawala-Jurnal Humaniora, 18(2), 229-234.

Wright, G. B. (2011). Student-Centered Learning in Higher Education. International Journal of Teaching and Learning In Higher Education, 23(1), 92-97.

Yeo, R. K. (2008). How Does Learning (Not) Take Place In Problem-Based Learning Activities In Workplace Contexts?. Human Resource Development International, 11(3), 317-330.

Zubaidah, S. U. M. J. (2017). Pembelajaran Kontekstual Berbasis Pemecahan Masalah Untuk Mengembangkan Kemampuan Berpikir Kritis. In Makalah disampaikan pada Seminar Nasional dengan tema Inovasi Pembelajaran Berbasis pemecahan Masalah dalam Pembelajaran Biologi di Universitas Muhammadiyah Makasar, Makasar (Vol. 6). 